ORIGINAL ARTICLE, MEDICINE

\title{
Landolphia owariensis Attenuates Alcohol-induced Cerebellar Neurodegeneration: Significance of Neurofilament Protein Alteration in the Purkinje Cells
}

\author{
Charles A. Oyinbo ${ }^{1,2}$, Patrick S. Igbigbi², Godwin O. Avwioro \\ ${ }^{1}$ Department of Human Anatomy, Faculty of Basic Medical Sciences, College of Health Sciences, Niger Delta University, Wilberforce \\ Island, Bayelsa State, Nigeria \\ ${ }^{2}$ Department of Anatomy and Cell Biology, Faculty of Basic Medical Sciences, Delta State University, Abraka, Delta State, Nigeria
}

\section{Correspondence: \\ Charles A. Oyinbo, Department of Human Anatomy, Faculty of Basic Medical Sciences, College of Health Sciences, Niger Delta Uni- versity, Wilberforce Island, Bayelsa State, Nigeria. \\ E-mail: \\ charles.oyinbo@mail.ndu.edu.ng charlesoyinbo@gmail.com Tel: +234-8134752933}

Received: 06 Sep 2015

Accepted: 08 July 2016

Published Online: 05 Oct 2016

Published: 23 Dec 2016

Key words: alcoholism, cerebellum, medicinal plant, nutraceuticals, neuroprotection

Citation: Oyinbo CA, Igbigbi PS, Avwioro GO. Landolphia owariensis attenuates alcohol-induced cerebellar neurodegeneration: significance of neurofilament protein alteration in the Purkinje cells.

Folia Medica 2016;58(4):241-249 doi: 10.1515/folmed-2016-0034
Background: Alcohol-induced cerebellar neurodegeneration is a neuroadaptation that is associated with chronic alcohol abuse. Conventional drugs have been largely unsatisfactory in preventing neurodegeneration. Yet, multimodal neuroprotective therapeutic agents have been hypothesised to have high therapeutic potential for the treatment of CNS conditions; there is yet a dilemma of how this would be achieved. Contrarily, medicinal botanicals are naturally multimodal in their mechanism of action.

Aim: The effect of L. owariensis was therefore assessed in alcohol-induced neurodegeneration of the cerebellar cortex in rats.

Materials and methods: Two groups of rats were oro-gastrically fed thrice daily with $5 \mathrm{~g} / \mathrm{kg}$ ethanol ( $25 \% \mathrm{w} / \mathrm{v})$, and $5 \mathrm{~g} / \mathrm{kg}$ ethanol ( $25 \% \mathrm{w} / \mathrm{v})$ plus L. owariensis (100 mg/kg body weight) respectively in diluted nutritionally complete diet $(50 \%$ $\mathrm{v} / \mathrm{v})$. A control group was correspondingly fed a nutritionally complete diet $(50 \%$ $\mathrm{v} / \mathrm{v}$ ) made isocaloric with glucose. Cytoarchitectural study of the cerebellar cortex was examined with H\&E. Immunocytochemical analysis was carried out with the use of monoclonal antibody anti-NF in order to detect alterations in the neuronal cytoskeleton.

Results: After 4 days of binge alcohol treatment, we observed that L. owariensis supplementation significantly lowered the levels of histologic and biochemical indices of neurodegeneration. The level of neurodegeneration and cytoarchitecture distortion of the cerebellar cortex of rats exposed to ethanol was reduced by L. owariensis. Neurofilament-immunoreactivity (NF-IR) was evoked in the Purkinje cells of rats that received $L$. owariensis supplement.

Conclusions: L. owariensis attenuates alcohol-induced cerebellar degeneration in the rat by alleviating oxidative stress and alteration of NF protein expression in the Purkinje cells.

\section{BACKGROUND}

Cerebellar degeneration is one of the long-term consequences of chronic alcohol consumption. It is characterised in about $60 \%$ of chronic alcoholics by a gradual developing gait ataxia. ${ }^{1}$ Cerebellar symptoms usually begin in the middle-aged individuals with a marked history of chronic alcohol abuse. ${ }^{2}$ Studies have shown that excessive exposure to alcohol leads to loss of neurones in the cerebellar cortex, including depletions of the cells in the Purkinje layer and vestibular nuclei. For some unknown reasons, cerebellar degeneration frequently begins in the superior vermis and spreads subsequently to the cerebellar hemispheres. ${ }^{3,4}$ However, in all instances, the Purkinje layer is noted for being the most vulnerable part of the cerebellar cortex and has been reduced in the vermis of chronic alcoholics to nearly half its normal population. ${ }^{1}$ The susceptibility of the Purkinje layer is independent of the lobe or lobule that constitute its anatomical location within the cerebellar cortex. The loss of Purkinje cells in the lateral lobes has also been associated with mental dysfunctions possibly due to the speculation that the cerebellum plays a critical role in the modulation of higher cerebral functions. ${ }^{1}$ The deleterious consequence of alcohol in the brain 
includes a direct toxic effect on Purkinje cells, an inhibitory role in the GABA neurogenic system, and the induction of lipid peroxidation which causes a reduction in the level of antioxidant concentrations in the brain. ${ }^{5}$ The loss of neurones in alcoholics is potentiated by vitamin B1 deficiency which results from a poor diet, a common feature with alcoholics. $^{6}$ This degenerative cascade included the direct toxic effect of vitamin B1 metabolism. Interestingly, studies suggested that a long-term alcohol exposure is not required to produce neurodegeneration. ${ }^{7,8}$ Indeed, neurodegeneration has been observed in the cerebellar cortex after a single binge alcohol episode. ${ }^{7,9}$ Interestingly, animal models of binge drinking showed a blood alcohol concentration (BAL) similar with those observed in chronic alcoholics. ${ }^{10}$ Hence, the critical issue with alcohol-driven neurodegeneration is that it does not depend purely on the duration of alcohol consumption, but essentially on the prevailing blood alcohol concentration per time. Regrettably, the pharmacological agents that are currently available for the treatment of alcohol use disorders (AUDs) have limited clinical efficacy. ${ }^{11}$ These medications primarily targets the motivational properties of alcohol, while its neurodegenerative effect, the key element that drives the progression into an alcohol addiction, is not managed by these specific remedies. ${ }^{11}$ It is now generally acknowledged that multimodal neuroprotective agents possess high therapeutic potentials for the treatment of CNS conditions. ${ }^{12}$ However, determining the conventional agents that would be safe and effective when formulated into a single agent with a multimodal mechanism of action remains critical. ${ }^{13}$ Experience has shown that it is difficult to gauge against the occurrence of complications in human trials; even in the non-multimodal trial protocol for CNS conditions. ${ }^{14,15}$ Fortunately, medicinal plants eliminate the problems of not knowing which conventional agents that would be unequivocally safe and effective as a formulated agent with a multimodal mechanism of action. Since the active principles in medicinal botanicals are already naturally combined, and are multimodal in their mechanism of action. ${ }^{16,17}$ Hence, they achieve a form of therapeutic synergy that is not classical with synthetic drugs. ${ }^{16,17}$

Landolphia owariensis P. Beauv (family Apocynaceae) is a medicinal plant that is widely distributed in the African continent. The previously reported pharmacological activities of $L$. owariensis includes antimicrobial, antioxidant, anti-inflammatory, anal- gesic, antiulcer and gastric anti-secretory effect. ${ }^{18}$ Most of the activities observed in the various anatomical segments of $L$. owariensis were attributed to its antioxidant constituents. Landolphia owariensis latex, a non-pH dependent biopolymer, showed great potential as a colon system specific drug release and controlled drug release. ${ }^{18}$ We hypothesised, judging from these pharmacotherapeutic properties, that $L$. owariensis could have a neuroprotective property. Hence, this study evaluated the effect of $L$. owariensis in the cerebellar cortex of rats exposed to excess ethanol. Neurofilament immunohistochemistry was done to assess the structural integrity of the neurones following $L$. owariensis administration.

\section{MATERIALS AND METHODS}

EXTRACTION, LD50 DETERMINATION, AND DOSE SELECTION The bark of the climber of $L$. owariensis was washed with water to remove debris. It was then dried at $50^{\circ} \mathrm{C}$ in an oven, after which it was comminuted into coarse powder. Two hundred grams (200 g) of coarse powder was macerated in $70 \%$ ethanol for 48 hours at room temperature $\left(26-36^{\circ} \mathrm{C}\right)$. Filtrates were concentrated in vacuum at $35^{\circ} \mathrm{C}$ to obtain the extract. Drying of extract was completely achieved in a desiccator as monitored by a silica-gel self indicator. The mean percentage yield was $15 \mathrm{~g}(7.5 \%)$.

The acute toxicity test (LD50) for L. owariensis (per oral) was determined by the Lorke's method. ${ }^{19}$ Briefly, extract of $L$. owariensis were administered at doses of 1000,2000 , and $3000 \mathrm{mg} / \mathrm{kg}$ respectively to three groups of rats ( $\mathrm{n}=3$ per group). No mortality was observed in any group over a period of 48 hours. Based on this, a dose of $100 \mathrm{mg} / \mathrm{kg}$ was selected since the long-term goal was to assess the viability of $L$. owariensis as a supplement.

\section{Animals}

Thirty adult male Wistar rats $(240-300$ g) were randomly divided into three groups consisting of ten animals per group: control (A), alcohol (B) and L. owariensis $(\mathrm{C})$. Rats were maintained on a 12 hour light-dark cycle and had free access to rodent chow and water. However, rats were deprived of chow overnight before the start of the experiment. Rats were handled according to the guidelines for animal research as detailed in the Guidelines for the Care and Use of Laboratory Animals by the National Research Council of the National Academy of Sciences. 
INDUCTION OF CEREBELLAR NEURODEGENERATION

Alcoholic cerebellar neurodegeneration was induced as previously described. ${ }^{7}$ Briefly, rats were infused through an orogastric gavage tube. Groups B and $\mathrm{C}$ rats were given an initial dose of $5 \mathrm{~g} / \mathrm{kg}$ ethanol in a solution of $25 \%(\mathrm{w} / \mathrm{v})$ ethanol in diluted nutritionally complete diet $\left(50 \% \mathrm{v} / \mathrm{v}\right.$, Vita milk ${ }^{\circledR}$ Ghana). In addition, group $\mathrm{C}$ rats received an extract of $L$. owariensis $(100 \mathrm{mg} / \mathrm{kg}$ body weight). These treatments were administered approximately 8 hourly for 4 consecutive days at about 6 a.m., 2 p.m., and 10 p.m. Except for the initial $5 \mathrm{~g} / \mathrm{kg}$ dose, subsequent doses were determined using a six-point intoxication scale. Control animals (group A) received a diet of Vita milk $^{\circledR}(50 \% \mathrm{v} / \mathrm{v})$ made isocaloric with glucose. During the four days of diet administration, rat chow was removed but water supply was freely available.

\section{BRAIN ISOLATION}

After 4 days, rats were sacrificed under anaesthesia. Rats for histological and immunohistochemical studies were anaesthetized with a mixture of ketamine $(75 \mathrm{mg} / \mathrm{kg})$ and diazepam $(2.5 \mathrm{mg} / \mathrm{kg})$ (ip) and were transcardially perfused with $10 \%$ phosphate buffer formal saline (0.1M, pH 7.4) solution. After complete perfusion, rats were rapidly decapitated and heads with the brain in situ in respective cranial cavities were completely immersed in $10 \%$ phosphate buffer formalin saline for 48 hours. Additionally, rats for biochemical investigation were rapidly anaesthetized with dichloromethane. The brain was then carefully removed and the cerebellum excised for biochemical investigation.

\section{Tissue Processing}

Brains that were already fixed in situ were exposed and excised from the respective cranial cavity. The cerebellum was carefully excised and transferred to ascending grades of alcohol for dehydration, and then cleared with xylene. They were embedded in paraffin wax overnight, serially sectioned at $5 \mu \mathrm{m}$ thickness with a rotary microtome, mounted on a glass slide and stained routinely with Haematoxylin and Eosin.

\section{Histological STUdy}

The representative sections ( $\mathrm{n}=6$ per group) were evaluated for damaged/degenerating neurones. They were identified by any of these three criteria: intensely eosinophilic cytoplasm, loss of Nissl substance and pyknotic nuclei/cell body shrinkage. A Purkinje cells-based semi-quantitative scale was adapted and scored thus: no degenerating Purkinje neuron $=0 ; 1 / 2$ degenerating Purkinje neurons $=1$; $3 / 4$ degenerating Purkinje neurons $=2 ; 5 / 6$ degenerating Purkinje neurons $=3$; more than 7 degenerating Purkinje neurons $=4 ; 6$ or more degenerating Purkinje neurons and neuropil vacuolation $=5$. The scores from all the sections from each group were averaged to give the histological index of neurodegeneration (HIN) for that particular group. Results of all three experimental groups were compared. All assessments were done using a $1 \mathrm{~mm} \times 2 \mathrm{~mm}$ grid graticulate at $400 \mathrm{X}$ magnification in randomly selected areas of section.

\section{IMMUNOHISTOCHEMICAL (IHC) STUDY}

The avidin-biotin immunoperoxidase technique developed by Hsu and colleague $(1981)^{20}$ for paraffin section immunohistochemistry was used in this study. ABC kit (Novocastra, Leica Biosystems Newcastle (UK), Mouse monoclonal anti-NF (Novocastra, Leica Biosystems Newcastle, UK, 1:100). Paraffin sections $3 \mu \mathrm{m}$ thick were mounted on slides and deparaffinized. The endogenous peroxidase activity was blocked with either 30\% hydrogen peroxidase in methanol (30 $\mathrm{min})$. For antigen retrieval, the sections were boiled in $0.01 \mathrm{M}$ citrate buffer $(15$ min). Non-specific binding was blocked with $1 \%$ BSA (bovine serum albumin fraction V) (Novocastra, Leica Biosystems Newcastle, UK) TRIS solution $1 \mathrm{~h}$. Thereafter, sections were incubated for 12 hours overnight $\left(2-6^{\circ} \mathrm{C}\right)$ with the primary antibodies. Sections were rinsed in PBS solution and incubated with the biotinylated secondary antibody (Novocastra, Leica Biosystems Newcastle, UK) and horseradish peroxidase-conjugated streptavidin (ABC kit, Novocastra, Leica Biosystems Newcastle, UK), for 60 minutes. The antigen-antibody sites were then visualised with 3,3'-diaminobenzidine tetrahydrochloride (DAB) (Novolink DAB, Novocastra, Leica Biosystems Newcastle, UK) for $15 \mathrm{~min}$. The sections were counterstained with hematoxylin, washed with tap water, dehydrated in alcohol, cleared in xylene and mounted in DPX.

Determination of ANTI-NF ReACtive AND NON-REACtive PURKINJE NEURONES

The anti-NF reactive versus non-reactive Purkinje neurone was counted using a $1 \mathrm{~mm} \times 5 \mathrm{~mm}$ grid graticulate at $400 \mathrm{X}$ magnification. Grid was orientated to enclose the Purkinje layer of the folium of randomly selected portions of the hemisphere. The score of all the sections from each group was averaged to give a final score for the particular 
group. Values were expressed as mean \pm SEM and were subjected to statistical analysis.

\section{DETERMINATION OF TISSUE LIPID PEROXIDATION}

Lipid peroxidation (LP), an indicator of tissue injury was estimated by measuring the tissue malondialdehyde (MDA) concentration. Tissue MDA levels were determined by the method described by Gutteridge and Wilkins. ${ }^{21}$ Briefly, samples of cerebellar cortex (approximately $0.2-0.3$ grams) were homogenised in 9 volume of $0.1 \mathrm{M}$ ice-cold Tris buffer, $\mathrm{pH}$ 7.4. The homogenate was then centrifuged at $3000 \mathrm{~g}$ for 15 - 20 minutes to remove debris. After centrifugation, the supernatant was carefully decanted to sterile plane tubes and was appropriately labelled and then temporally stored at $-15^{\circ} \mathrm{C}$. Tissue malondialdehyde level was determined in the homogenate as previously described. ${ }^{21}$ Briefly, $0.6 \mathrm{ml}$ of the supernatant was added to $3 \mathrm{ml}$ of glacial acetic acid in a test tube followed by the addition of $3 \mathrm{ml}$ of $1 \%$ thiobarbituric acid (TBA) in $0.2 \% \mathrm{NaOH}$. The test tube was immersed in a boiling water bath for 15 minutes and then allowed to cool. The absorbance of the red coloured product formed was read in a spectrophotometer at $532 \mathrm{~nm}$ against a reagent blank to which was added $0.6 \mathrm{ml}$ of distilled water instead of tissue extract. The concentration of MDA in the sample was estimated and expressed as $\mathrm{mmol} / \mathrm{g}$ wet tissue.

\section{Photomicrography}

The microscopic image was transmitted to an LCD monitor by a microscope-camera-monitor composite contrivance as previously described. ${ }^{22}$ Digital photomicrographs were captured directly by the attached computer, labelled appropriately and stored for analysis.

\section{Statistical analysis}

A one-way analysis of variance and the Tukey's post hoc test were used to assess the significance of differences between groups (GraphPad Prism 5, San Diego, USA). Values were generally expressed as the mean \pm SEM. A $p$ value of $\alpha<0.05$ was considered statistically significant.

\section{RESULTS}

\section{Histological study}

The semi-quantitative scale values ranged from 0 to 5 ; with 0 indicating no degeneration and 5 indicating massive degeneration. The mean value of any particular group constituted the histological index of neurodegeneration (HIN) for that group, which gave an estimate of the extent of neurodegeneration within the group. HIN was highest in the alcohol group and the lowest in the control group (Table 1). There were significant differences amongst the three groups. The control differs significantly from the alcohol and L. owariensis groups $(\mathrm{p}<0.001$ and $\mathrm{p}<0.05$, respectively). Additionally, L. owariensis administered to alcohol-exposed rats significantly lowered the histological index of neurodegeneration compared to the rats exposed to alcohol without L. owariensis administration $(\mathrm{p}<0.05)$. Suggestive, though based on morphological characterization, that L. owariensis may have safeguarded the cells of the cerebellar cortex from alcohol-induced damage.

EFFECT OF $L$. OWARIENSIS ON TISSUE MDA CONCENTRATION To assess the extent of tissue damage associated with or without our treatment regime, the level of lipid peroxidation was assessed by tissue MDA concentration. The MDA level was the highest in the alcohol group and the lowest in the control

Table 1. Indices of degenerative changes and numbers of anti-NF reactive Purkinje cells

\begin{tabular}{|c|c|c|c|}
\hline Groups & HIN & LP (mmol/g tissue) & $\begin{array}{c}\text { Anti NF reactive } \\
\text { Purkinje cells }\left(\text { no } / 5 \mathrm{~mm}^{2}\right)\end{array}$ \\
\hline Control (A) & $0.4 \pm 0.24$ & $62.6 \pm 12.0$ & $0 \pm 0$ \\
\hline Alcohol (B) & $1.9 \pm 0.32$ & $118.4 \pm 10.4$ & $0 \pm 0$ \\
\hline \multirow[t]{2}{*}{ L. owariensis (C) } & $0.8 \pm 0.37$ & $85.9 \pm 8.8$ & $6.6 \pm 0.89$ \\
\hline & $\begin{array}{l}\text { A significantly different from } \\
\text { B }(\mathrm{p}<0.001) \& \mathrm{C}(\mathrm{p}<0.05) \\
\text { C significantly different from } \\
\text { B }(\mathrm{p}<0.05)\end{array}$ & $\begin{array}{l}\text { A significantly different from } \\
\text { B }(p<0.001) \text { \& } C(p<0.05) \\
\text { B significantly different from } \\
\text { C }(p<0.01) \text {. }\end{array}$ & $\begin{array}{l}\text { C significantly } \\
\text { different from } \\
\text { A \& B }(p<0.001)\end{array}$ \\
\hline
\end{tabular}

$\mathrm{HIN}=$ histological index of neurodegeneration, $\mathrm{LP}=$ lipid peroxidation 
group (Table 1). The administration of $L$. owariensis lowered the mean value of cerebellar cortical MDA level compared to the rats that were fed with only alcohol. There were statistically significant differences between the control group and the alcohol group $(\mathrm{p}<0.001)$ and between alcohol group and $L$. owariensis group $(\mathrm{p}<0.01)$. However, there was also a significant difference between the control group and the L. owariensis group $(\mathrm{p}<0.05)$, indicating that $L$. owariensis could not completely eradicate neurodegeneration, but could only reduce it.

\section{NEUROFILAMENT (NF) IMMUNOHISTOCHEMISTRY}

L. owariensis administered as a supplement to alcohol-fed rats show differential expressions between neuronal soma and axons. The neuronal soma in the molecular, Purkinje, and granular layers were weakly sensitive to NF labelling in the control and alcohol groups (Figs 2A \& B). However, L. owariensis seem to upregulate NF-IR in the Purkinje cells
(Fig. 2C) compared to the other groups. We found that axons in the alcohol group showed NF-IR in the white matter, and that the administration of $L$. owariensis to alcohol-fed rats reduced the intensity of NF-protein labelling in the white matter.

Anti-NF REACtive VERSus NON-REACtive Purkinje NEURONE

In each grid field of $5 \mathrm{~mm}^{2}$ graticulate at $400 \mathrm{X}$ magnification, we counted the total numbers of Purkinje neurone and then counted the numbers of anti-NF reactive Purkinje neurone. The mean numbers of Purkinje neurone $\left(\mathrm{n} / 5 \mathrm{~mm}^{2}\right)$ for the control, alcohol and $L$. owariensis groups were $9.0 \pm 0.32$, $5.6 \pm 0.51$ and $7.2 \pm 0.37$, respectively. ANOVA result showed that the mean numbers of Purkinje neurone differ significantly amongst the groups (Fig. 2). There was a significant increase in the number of Purkinje neurone in the cerebellar cortex of the rats that received L. owariensis supplement compared

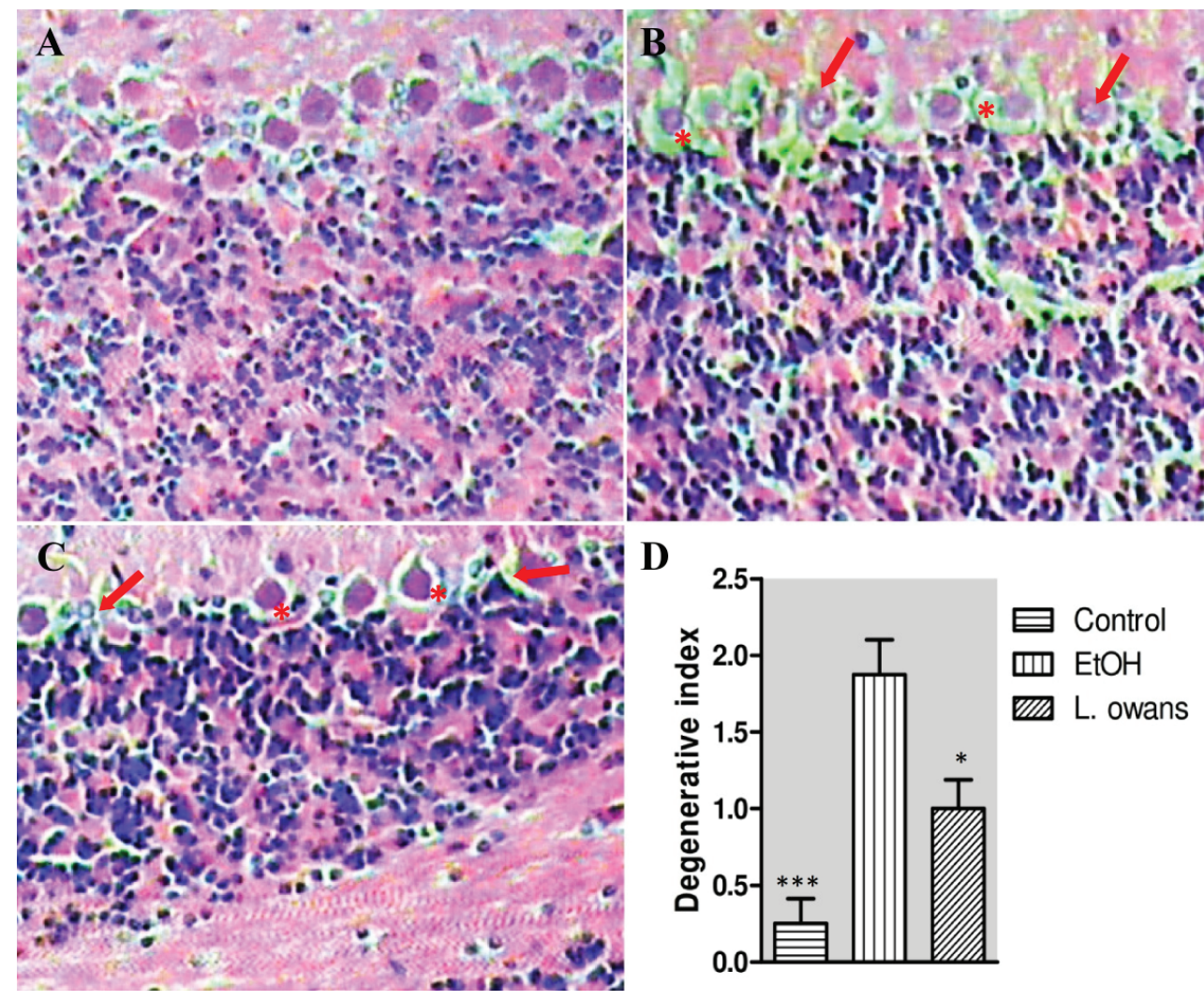

Legend: (A) The representative section of the control group showed normal cytoarchitectural profile with no degenerating neurones. (B) The representative section of rats exposed only to alcohol showed Purkinje cells degeneration (red arrow head), perineural vacuolization of Purkinje cells (asterisks), shrunken Purkinje cells with either pyknotic or karyorrhectic nuclei and Purkinje cells with condensed nuclei. Also notice spaces around the molecular and Purkinje layers suggesting concurrent swelling/degeneration of Purkinje cells. (C) The representative section of L. owariensis-treated rats showed Purkinje cells degeneration and perineural vacuolization of Purkinje cells. Observe that degenerative changes of the Purkinje cells were generally modest. (D) One-way ANOVA results showed that L. owariensis fed to alcohol-exposed rats significantly reduced the level of Purkinje cells degeneration.

Figure 1. Effect of L. owariensis on alcohol-reduced cerebellar neurodegeneration (H\&E x 250). 
to the rats exposed to alcohol without supplement $(p<0.05)$. This suggested, though incidentally, that L. owariensis supplementation to alcohol-exposed rats could reduce the level of alcohol-induced neurodegeneration. The mean values of anti-NF reactive Purkinje neurone in the control, alcohol and L. owariensis groups were $0 \pm 0,0 \pm 0$, and $6.6 \pm 0.40$, respectively. NF-positive neurones were not visible in the other groups, which corresponded to a statistically significant value of $p<0.001$. Correspondingly, the proportion of the anti-NF non-reactive neurone also varies significantly $(\mathrm{p}<0.001)$ among the groups.
Although NF non-reactive neurones were present in the $L$. owariensis group, they were outnumbered in a ratio of $1: 11$.

\section{DISCUSSION}

The present study examined the neuroprotective potentials of oral administration of $L$. owariensis in a rat model of cerebellar alcoholic neurodegeneration. L. owariensis demonstrated a considerable neuroprotective effect in cerebellar alcoholic neurodegeneration. Animals treated with $L$. owariensis
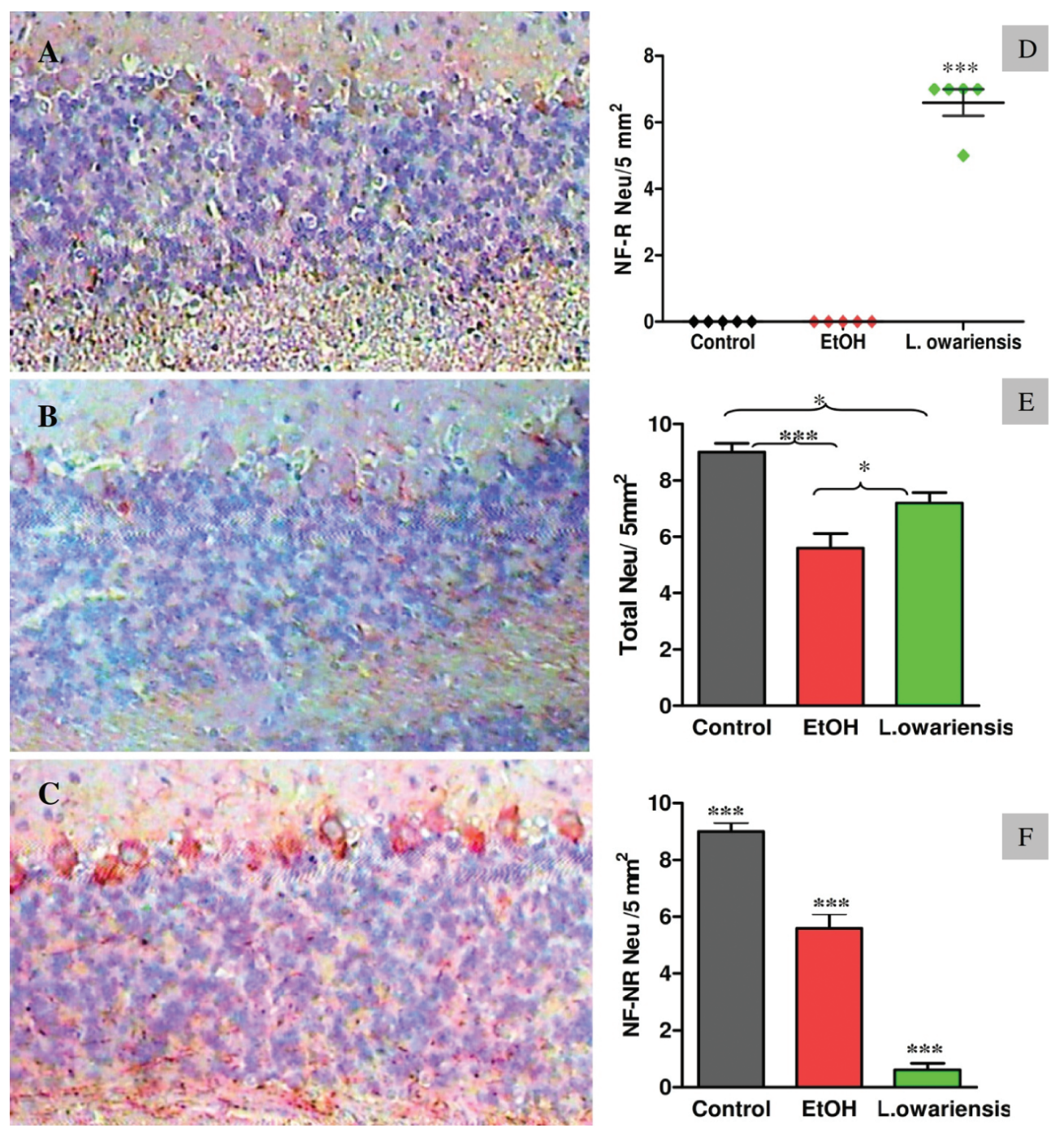

Legend: (A) The representative section of the control group showed predominantly anti-NF non-reactive Purkinje cells. (B) The representative section of rats exposed only to alcohol also showed predominantly anti-NF non-reactive Purkinje cells. There was no appreciable alteration in the expression of NF proteins in the Purkinje cells in groups A and B. (C) The representative section of $L$. owariensis-treated rats showed predominantly anti-NF reactive Purkinje cells. (D) A oneway ANOVA showed that the proportion of anti-NF reactive neurone in the L. owariensis-treated rats differ significantly from the control and alcohol groups $(\mathrm{p}<0.001)$. (E) A one-way ANOVA further showed that the total numbers of Purkinje cells in the L. owariensis-treated rats differ significantly from the EtOH group $(\mathrm{p}<0.05)$. (F) Similarly, the proportions of anti-NF non-reactive Purkinje cells differ significantly amongst the groups $(p<0.001)$. There was also no appreciable expression of NF proteins in the molecular and granular layers in all the three groups.

Figure 2. Effect of L. owariensis on NF protein expression in alcohol exposed rats (NF labelling x 250). 
exhibited reduced tissue destruction and reduced oxidative stress. Research has shown that the Purkinje layer is the most susceptible part of the cerebellar cortex. Our study shows that L. owariensis generally reduced the severity of neurodegeneration and distortions of the cortical cytoarchitecture in cerebellar alcoholic neurodegeneration. It also suggested that L. owariensis significantly attenuated the level of alcohol-induced degeneration of the Purkinje neurones. This suggests, though based on the morphological characterization of the Purkinje neurones, that $L$. owariensis may have safeguarded the cells of the cerebellar cortex from alcohol insults. Although studies have highlighted the neuroprotective potentials of medicinal botanical in alcoholinduced cerebellar insults ${ }^{23,24}$ none of them have yet demonstrated such potential with $L$. owariensis on cerebellar alcoholic neurodegeneration.

Free radical-mediated damage is common in the aetiology of most degenerative conditions of the brain because the brain characteristically has high lipid content and high oxygenation. Though high oxygenation yields large quantities of ROS, several parts of the brain that are rich in iron also promote the production of more ROS, which is involved in a cascade that exuberates neuronal injury, including an ROS-driven cellular damage mediated by lipid peroxidation. ${ }^{23,25}$ Furthermore, in alcohol metabolism, several intermediate products forms proteins adducts and complexes that generate more ROS in the brain and when the production of ROS overwhelms the endogenous antioxidant defences, a self-perpetuating free radical damaging reaction of lipid peroxidation is initiated which involves membrane damage, organelle dysfunction, and calcium dyshomeostasis. ${ }^{25,26}$ Ironically, the antioxidant defence system is poor in the brain. ${ }^{27}$ Therefore, salvaging the cerebellum from oxidative damage by using antioxidant therapies is an important area of continuing investigation in alcoholic brain degeneration in general, and in alcoholic cerebellar degeneration in particular. Interestingly, our study also shows that $L$. owariensis can significantly lower the level of lipid peroxidation in cerebellar cortex of alcohol-exposed rats. However, it could not completely eradicate cerebellar neurodegeneration mediated by lipid peroxidation, but could only attenuate or reduce it.

Our result confirmed that the unstressed neuronal perikaryon is not a domain for strong neurofilamentimmunoreactivity (NF-IR). Nonetheless, the neuronal perikarya may strongly express NF protein in some neurodegenerative diseases ${ }^{28,29}$ as observed in the present study. Furthermore, we observed wide spread NF-IR in the white matter of the alcohol group, which was however reduced by $L$. owariensis supplementation. Neurofilament alterations have been associated with many CNS diseases including those affecting the cerebellum. ${ }^{28,29}$ Abnormalities in neurofilament expression, transport and regulation have been identified in several neurodegenerative diseases. Neurofilament protein alterations are observed in many neurodegenerative diseases, such as Alzheimer, Parkinson, amyotrophic lateral sclerosis, and Charcot-Marie-Tooth. Many NF protein alterations potentially lead to the accumulation of neurofilaments over a long term. The neuroprotective potentials of medicinal plants in the cerebellar cortex have been shown in both in vitro ${ }^{24}$ and in $v i v o^{23}$ studies. Immunohistochemical evidence from our study indicated that L. owariensis caused an increase in NF protein expression in the Purkinje neurones. A critical question arising from this study is whether the increased NF protein expression we observed is beneficial or detrimental to the Purkinje cells during alcohol toxicity. As shown in this study, anti-NF-reactive Purkinje cells overwhelmingly outnumbered the anti-NF non-reactive Purkinje cells and this coincided with a significant increase in the numbers of Purkinje cells in the L. owariensis group compared to the alcohol group. Putting these in frame with our histological and biochemical analysis which shows that $L$. owariensis causes a reduction in the number of degenerating Purkinje cells and attenuates the degree of lipid peroxidation in the cerebellar cortex (Fig. 1 and Table 1), we are persuaded that the activation of NF protein triggered by $L$. owariensis administration was plausibly beneficial to the Purkinje neurones. It is widely accepted that despite all the diverse cellular functions that are attributed to the various form NF protein, they are, however, predominantly involved in providing structural stability to the neurones. ${ }^{28,29}$

Hence we opined that the increased expression of NF protein in the Purkinje cells of the $L$. owariensis-treated rats may be part of an elaborate mechanism that confers a sort of cellular resistance to alcohol insults. Stated differently, we opined that L. owariensis potentiates the structural stabilising role of the neurofilament in the Purkinje cells of alcohol-exposed rat. The importance of Purkinje cells is perhaps emphasised by the fact that they constitute the only output neurone of the cerebellar cortex and consequently any alteration in their 
function has significant impact on the function of the cerebellum as a whole. ${ }^{30}$

\section{CONCLUSION}

The results of this study suggested that $L$. owariensis attenuates alcohol-induced cerebellar neurodegeneration by alleviating oxidative stress and alteration of NF protein expression. Histological, biochemical, and NF-labelling examinations, all revealed improved outcomes in animals treated with $L$. owariensis. It is obvious that clinically efficacious therapies could be achieved in a multimodal therapeutic strategy targeting different pathological pathways because the pathophysiology of alcohol-induced damage to the brain is inherently complicated. This study has therefore repurposed L. owariensis as possibly a medicinal plant that can be developed into a nutraceutical for the management of neurodegeneration.

\section{REFERENCES}

1. Harper C. The neuropathology of alcohol-related brain damage. Alcohol 2009;44(2):136-40.

2. Barsottini OG, Albuquerque MV, Braga-Nofo P, et al. Adult onset sporadic ataxias: a diagnostic challenge. Arq de Neuro-psiquiatr 2014;72(3):232-40.

3. Davis LE, King MK, Schultz JL. Fundamentals of neurologic disease. New York, NY: Demos Medical Publishing; 2005.

4. Yokota O, Tsuchiya K, Terada S, et al. Frequency and clinicopathological characteristics of alcoholic cerebellar degeneration in Japan: a cross-sectional study of 1,509 postmortems. Acta Neuropathol 2006;112:43-51.

5. Jaatinen P, Rintala J. Mechanisms of ethanol-induced degeneration in the developing, mature, and aging cerebellum. Cerebellum 2008;7:332-47.

6. Andersen BB. Reduction of Purkinje cell volume in cerebellum of alcoholics. Brain research 2004;1007(1):10-8.

7. Obernier JA, White AM, Swartzwelder HS, et al. Cognitive deficits and CNS damage after a 4-day binge ethanol exposure in rats. Pharmacol Biochem Behav 2002;72(3):521-32.

8. Hermens DF, Lagopoulos J, Tobias-Webb J, et al. Pathways to alcohol-induced brain impairment in young people: a review. Cortex 2013;49(1):3-17.

9. McQueeny T, Schweinsburg BC, Schweinsburg $\mathrm{AD}$, et al. Altered white matter integrity in adolescent binge drinkers. Alcohol Clin Exp Res 2009;33(7):1278-85.

10. Parry-Jones BL, Vaughan FL, Miles CW. Traumatic brain injury and substance misuse: a systematic review of prevalence and outcomes research (1994-
2004). Neuropsychol Rehabil 2006;16(5):537-60.

11. Litten RZ, Egli M, Heilig M, et al. Medications development to treat alcohol dependence: a vision for the next decade. Addiction Biology 2012;17(3):513-27.

12. Mechanick JI, Zhao S, Merrill WC. Dietary supplements and nutraceuticals. In: Mechanick JI, Michael Via, Zhao S, editors. Molecular Nutrition: The Practical Guide. The Endocrine Society 2015:80-118.

13. Thuret S, Moon LD, Gage, FH. Therapeutic interventions after spinal cord injury. Nat Rev Neurosci 2006;7:628-43.

14. Pointillart V, Petitjean ME, Wiart L, et al. Pharmacological therapy of spinal cord injury during the acute phase. Spinal Cord 2000;38:71-6.

15. Thomsen GM, Gowing G, Svendsen S, et al. The past, present and future of stem cell clinical trials for ALS. Experimental neurology 2014;262:127-37.

16. Yu D, Thakor D K, Han I, et al. Alleviation of chronic pain following rat spinal cord compression injury with multimodal actions of huperzine A. Proc Natl Acad Sci USA 2013;110(8):E746-E755.

17. Shen J, Xu X, Cheng F, et al. Virtual screening on natural products for discovering active compounds and target information. Current Medicinal Chemistry 2003;10(21):2327-42.

18. Okonkwo TJ, Osadebe PO. Isolation and characterization of potential bioactive compounds from $L$. owariensis P. Beauv Stringy Seed Pulp. International Journal of Applied Research in Natural Products 2013;6(3):28-38.

19. Lorke D. A new approach to practical acute toxicity testing. Arch Toxicol 1983;54:275-87.

20. Hsu SM, Raine L, Fanger H. Use of avidin-biotin peroxidase complex $(\mathrm{ABC})$ in immunoperoxidase techniques: A comparison between $\mathrm{ABC}$ and unlabeled antibody (PAP) procedures. J Histochem Cytochem 1981;29:577-80.

21. Gutteridge JM, Wilkins S. Copper-dependent hydroxyl radical damage to ascorbic acid: Formation of a thiobarbituric acid-reactive product. FEBS Lett. 1982;137:327-40.

22. Yonguc GN, Ozdemir MB, Kucukatay V, et al: Memory function and total pyramidal neuron number of hippocampus in streptozotocin induced diabetic rats. J Neurol Sci (Turk) 2014;31:461-73.

23. Noorafshan A, Rashidiani-Rashidabadi A, KarbalayDoust $\mathrm{S}$, et al. Curcumin can prevent the changes in cerebellar structure and function induced by sodium metabisulfite in rat. Experimental Neurobiology 2013;22(4):258-67.

24. Salavati P, Ramezani M, Monsef-Esfahani HR, et al. Neuroprotective effect of total and sequential extract of Scrophularia striata Boiss. in rat cerebellar granule neurons following glutamate-induced 
neurotoxicity: an in-vitro study. Iran J Pharm Res 2013;12(2):389-94.

25. Uttara B, Singh AV, Zamboni P, et al. Oxidative stress and neurodegenerative diseases: a review of upstream and downstream antioxidant therapeutic options. Current Neuropharmacology 2009;7(1):65.

26. Shan LQ, Ma S, Qiu XC, et al. Hydroxysafflor Yellow A protects spinal cords from ischemia/ reperfusion injury in rabbits. BMC neuroscience. 2010;11(1):98.

27. Jovanovic Z. Antioxidative defense mechanisms in the aging brain. Archives of Biological Sciences 2014;66(1):245-52.

28. Liu Q, Xie F, Alvarado-Diaz A, et al. Neurofilamentopathy in neurodegenerative diseases. The Open Neurology Journal 2011;5:58-62.

29. Yuan A, Rao MV, Nixon RA. Neurofilaments at a glance. Journal of Cell Science 2012;125(14):257-63.

30. Redondo J, Kemp K, Hares K, et al. Purkinje cell pathology and loss in multiple sclerosis cerebellum. Brain Pathology 2015;25(6):692-700.

\title{
Ландольфия (Landolphia owariensis) снижает церебральную нейроде- генерацию, вызванную алкоголем: значение изменения нейрофила- мента белка в клетках Пуркинье
}

\author{
Чарльз А. Ойнбо 1,2, Патрик С. Игбигли², Годвин Авиоро 2 \\ ${ }^{1}$ Кафедра анатомии человека, Факультет основных медицинских наук, Колледж науки о здоровье, Университет "Дельта \\ Нигера“, Остров Уилберфорс, штат Байельса, Нигерия \\ 2 Кафедра анатомии и клеточной биологии, Факультет основных медицинских наук, Университет штата Дельта, Абрака, \\ штат Дельта, Нигерия
}

\section{Адрес для корреспонденции: Чарльз А. Ойнбо, Кафедра анатомии человека, Факультет основных медицинских наук, Колледж науки о здоровье, Университет "Дельта Нигера", Остров Уилберфорс, штат Байельса, Нигерия \\ E-mail: \\ charles.oyinbo@mail.ndu.edu.ng charlesoyinbo@gmail.com Тел.: +234-8134752933}

Дата получения: 06 сентября 2015 г.

Дата приемки: 08 июля 2016 г. Дата онлайн публикации: 05 октября 2016 г.

Дата публикации: 23 декабря 2016 г.

Ключевые слова: алкоголизм, малый мозг, лекарственное растение, нутрицевтика, нейропротекция

\section{Образец цитирования:}

Oyinbo CA, Igbigbi PS, Avwioro GO. Landolphia owariensis attenuates alcohol-induced cerebellar neurodegeneration: significance of neurofilament protein alteration in the Purkinje cells.

Folia Medica 2016;58(4):241-249 doi: 10.1515/folmed-2016-0034
Контекст: Церебральная нейродегенерация, вызванная алкоголем, представляет собой нейроадаптацию, связанную с хроническим злоупотреблением алкоголем. Конвенциональные лекарства в преобладающей степени дают неудовлетворительный результат при предотвращении нейродегенерации. Несмотря на то, что мультимодальные нейропротективные терапевтические агенты гипотетически обладают высоким терапевтическим потенциалом в плане лечения состояний центральной нервной системы, на повестке дня все еще стоит дилемма относительно достижения данного потенциала. В противовес этому, лекарственные растения являются натуральными мультимодальными агентами, включенными в их механизм действия.

Цель: Оценка воздействия L. owariensis на нейродегенерацию церебральной коры мозга крыс, вызванную алкоголем.

Материалы и методы: Двум группам крыс по три раза в день с помощью орогастрального зонда вливалось по 5 г/кг этанола $(25 \% \mathrm{w} / \mathrm{v})$ и 5 г/кг этанола $(25 \% \mathrm{w} / \mathrm{v})$ с добавлением L. owariensis (100 mg/kg живого веса) в виде разбавленного полноценного корма (50\% v/v). Контрольная группа питалась полноценной изокалорической пищевой смесью (50\% v/v) с глюкозой. Исследование клеточной архитектоники коры малого мозга было проведено с помощью Н\&Е. Иммуно-цитохимический анализ проведен с использованием моноклонального антитела анти-NF с целью выявления изменений в цитоскелете нейронов.

Результаты: Спустя 4 дня после подачи алкоголя было установлено, что при добавлении L. owariensis значительно снижается уровень нейродегенеративных гистологических и биохимических показателей. Уровень нейродегенерации и искажения архитектуры клеточной сети церебральной коры мозга крыс, находящихся под воздействием этанола, снизился под влиянием $L$. owariensis. NF-IR вызван в клетках Пуркинье у крыс, которые получили добавky L. owariensis.

Заключение: L. owariensis подавляет церебральную дегенерацию, Вызванную алкоголем у крыс, за счет снижения уровня оксидативного (окислительного) стресса и изменения NF экспрессии белков в клетках Пуркинье. 